\title{
EVALUASI PERUBAHAN ADEKUASI HEMODIALISA TERHADAP DUKUNGAN KELUARGA PASIEN GAGAL GINJAL KRONIK YANG DIBERIKAN RANGE OF MOTION
}

\section{EVALUATION OF HEMODIALISA ADEKUATION CHANGE TO FAMILY SUPPORT PATIENT FAILS OF CHRONIC TYPES GIVEN RANGE OF MOTION}

\author{
Fitria Hasanuddin \\ Akper Muhammadiyah Makassar \\ fitria_has2008@yahoo.co.id
}

081342298060

\begin{abstract}
Chronic Kidney Disease (CKD) is a problem that occurs in the decline in kidney function because the kidneys become vital organs in maintaining body health and hemodialysis into action to remove the rest of the metabolism that can not be released by the body. Continuous kidney damage and glomerular filtration rate (GFR) continue to decrease which will cause uremic effects.

This study aims to see changes in the evaluation of hemodialysis adequacy and the influence of family support on patients with chronic renal failure given range of motion (ROM) at the Regional General Hospital of Labuang Baji Makassar.

This research is a quantitative research of cohort analytic survey design with longitudinal explorative approach. The number of respondents in the study were 14 people, divided into 2 groups: 9 respondents were given ROM and hemodialysis intervention and 5 respondents who underwent hemodialysis therapy as control group. Test statistic paired t test to see difference before and after given range of motion in intervention group and control group.

The result of this research is that after the 8th visit in the intervention group (ROM + Hemodialysis) obtained URR value $p=0.05$ (Mean 76.00; SD 11.32) which mean there is significant difference of URR value after done range of motion. And Kt / V in both groups ie intervention and control group obtained p value $>0.05$ means there is no difference before and after giving range of motion. In Pearson correlation test data no influence of family support on the change of hemodialysis adequacy value obtained p value $>0.05$.

The conclusions of this study were statistically unaffected, but clinically impacted changes in the value of hemodialysis adequacy with respect to duration of hemodialysis, hemodialysis frequency and dry weight.
\end{abstract}

Key words: Family support, Hemodialysis adequacy, Range of motion (ROM.)

\begin{abstract}
ABSTRAK
Gagal Ginjal Kronik (GGK) atau Chronic Kidney Diseases (CKD) merupakan masalah yang terjadi pada penurunan fungsi ginjal dikarenakan ginjal menjadi organ vital dalam menjaga kesehatan tubuh dan hemodialisa menjadi tindakan untuk mengeluarkan sisa metabolisme yang
\end{abstract}


tidak mampu dikeluarkan oleh tubuh. Kerusakan ginjal secara berkelanjutan dan laju filtrasi glomerulus (GFR) terus semakin menurun yang akan menimbulkan efek uremik.

Penelitian ini bertujuan untuk melihat perubahan evaluasi adekuasi hemodialisa dan pengaruh dukungan keluarga pada pasien gagal ginjal kronik yang diberikan range of motion (ROM) di Rumah Sakit Umum Daerah Labuang Baji Makassar.

Penelitian ini merupakan penelitian kuantitatif desain survey analitik cohort dengan pendekatan eksploratif longitudinal. Jumlah responden yang pada penelitian sebanyak 14 orang, yang dibagi dalam 2 kelompok yaitu 9 responden diberikan intervensi $R O M$ dan hemodialisa serta 5 responden yang menjalani terapi hemodialisa sebagai kelompok kontrol. Uji statistic paired t test untuk melihat perbedaan sebelum dan setelah diberikan range of motion pada kelompok intervensi dan kelompok kontrol.

Hasil pada penelitian ini yakni setelah kunjungan ke-8 pada kelompok intervensi (ROM+Hemodialisa) diperoleh nilai $U R R p=0,05$ (Mean 76,00; SD 11,32) yang berarti terdapat perbedaan yang signifikan nilai $U R R$ setelah dilakukan range of motion. Dan Kt/V pada kedua kelompok yaitu kelompok intervensi dan kontrol diperoleh nilai $p>0,05$ artinya tidak terdapat perbedaan sebelum dan setelah pemberian range of motion. Pada Uji pearson correlation didapatkan data tidak ada pengaruh dukungan keluarga terhadap perubahan nilai adekuasi hemodialisa diperoleh nilai $p>0,05$.

Simpulan penelitian ini secara statistic tidak memberi pengaruh namun secara klinisi memberi dampak perubahan pada nilai adekuasi hemodialisa dengan memperhatikan lamanya hemodialisa, frekuensi hemodialisa dan berat badan kering.

Kata kunci: Adekuasi hemodialisa, Dukungan keluarga, Range of motion (ROM.)

\section{PENDAHULUAN}

Gagal Ginjal Kronik (GGK) atau Chronic Kidney Diseases (CKD) merupakan masalah yang terjadi pada penurunan fungsi ginjal dikarenakan ginjal menjadi organ vital dalam menjaga kesehatan tubuh. Penurunan fungsi ginjal menyebabkan ginjal tidak dapat mempertahankan keseimbangan metabolisme, cairan dan elektrolit yang dapat mengakibatkan uremia: retensi urea dan sampah nitrogen lain dalam darah (Bare \& Smeltzer, 2004). Penyakit ginjal kronis tidak dapat disembuhkan atau dipulihkan ketika terjadi penurunan fungsi ginjal dan massa ginjal yang tersisa tidak dapat lagi menjaga lingkungan internal tubuh, maka akibatnya terjadi gagal ginjal atau CKD stadium 5 dan sering disebut penyakit ginjal stadium akhir (ESRD) (Black \& Hawks, 2014). Prevalensi kejadian gagal ginjal kronik di dunia menurut The United States Renal Data System (USRDS) akhir tahun 2009, lebih dari 871.000 orang dirawat karena ESRD di Amerika Serikat. Menurut data dari Riset Kesehatan Dasar (2013), prevalensi gagal ginjal kronik di Indonesia sekitar 0,2 \%. Sulawesi Selatan menjadi urutan ke lima setelah Sulawesi Tengah, Sulawesi utara, Aceh dan Gorontalo. Adapun angka kejadian 
di Sulawesi Selatan sebanyak 0,3\%, sementara berdasarkan kelompok umur ditemukan kelompok umur $\geq 75$ tahun dengan $0,6 \%$ tertinggi daripada kelompok umur yang lain dan kejadian pada laki - laki 0,3\% lebih tinggi dari perempuan. Tingginya angka kejadian tersebut dikarenakan oleh beberapa faktor penyebab dari penyakit sistemik dan kardiovaskuler. Banyak penyakit yang bisa muncul secara bersamaan dengan ESRD. Dalam hal ini infeksi dan penyakit kardiovaskuler merupakan penyebab umum terjadinya penyakit ESRD yang dapat mengakibatkan kematian. Tingginya angka kejadian ESRD dikarenakan kejadian diabetes dan hipertensi turut mempengaruhi yakni sebesar $34 \%$ dan $21 \%$ dari total kasus. Glomerulus menjadi urutan ketiga $17 \%$ penyebab ESRD (Price \& Wilson, 2005).

Tingginya angka kejadian penyakit renal tahap akhir disebabkan karena penyakit sistemik seperti diabetes melitus, glomerulus nefritis pielonefritis dan hipertensi yang tidak dapat dikontrol. Dengan berbagai macam penyakit yang bisa menyebabkan gagal ginjal kronik dan tingginya angka kejadian baik di Amerika Serikat maupun di Indonesia, maka dapat di lihat bahwa kerusakan ginjal bisa terjadi dimana saja. Kerusakan ginjal secara berkelanjutan dan jumlah nefron berfungsi semakin kurang dan laju filtrasi glomerulus (GFR) terus semakin menurun. Tubuh menjadi kelebihan cairan dan sampah sisa metabolisme semakin banyak. Karena terjadi penurunan fungsi ginjal maka fungsi eksresi mengalami gangguan. Ketika GFR turun di bawah $10-20 \mathrm{ml} / \mathrm{menit}$, efek uremik timbul pada tubuh klien dan upaya penanganannya tidak diterapi dengan dialisis atau transplantasi, maka uremia dan kematian bisa terjadi pada klien (Bayhakki, 2013). Angka bertahan hidup 1 tahun pasien untuk pasien yang menjalani terapi hemodialisa diperkirakan $79 \%$, namun angka bertahan hidup jangka panjang turun hingga $33 \%$ untuk 5 tahun (NKUDIC, 2009). Hal ini menjadikan terapi hemodialisa menjadi pilihan pengobatan dari gagal ginjal kronik. Pada penelitian yang dilakukan oleh Alimanesh dkk (2010), dikatakan bahwa usia rata -rata pasien adalah 16 sampai 54 tahun, mean Kt/V 0,97 $\pm 0,42$ yang secara signifikan lebih tinggi pada pasien yang menerima 3 kali perminggu dibandingkan dengan 2 kali perminggu dengan $p=0,03$ dan terdapat 32,1 $\%$ dari semua pasien mencapai nilai $\mathrm{Kt} / \mathrm{V}$. Dukungan keluarga merupakan satu factor yang mempengaruhi keputusan insiasi hemodialisa (Sunarni,2009). Respon yang memiliki dukungan yang baik tidak akan menunda inisiasi hemodialisa dan 
berpengaruh dalam menjalani terapi hemodialisa (Tonapa,2016). Berdasarkan uraian di atas penulis tertarik untuk melakukan penelitian evaluasi perubahan hemodialisa dan dukungan keluarga pasien gagal ginjal kronik yang diberikan range of motion.

\section{METODE}

\section{Desain, tempat dan waktu}

Desain penelitian ini merupakan penelitian kuantitatif desain survey analitik cohort dengan pendekatan eksploratif longitudinal.

Tempat dan waktu di Rumah Sakit Umum Daerah Labuang Baji November Desember 2017. Analisa data dilakukan dengan program SPSS 21 for Windows dan uji statistik dengan menggunakan uji univariat dengan mean dan standar deviasi untuk data numerik serta frekuensi persen untuk data kategorik, uji bivariat paired $t$ test dan pearson corelation.

\section{Jumlah dan cara pengambilan subjek penelitian}

Populasi penelitian adalah semua pasien yang menjalani terapi hemodialisa. Didapatkan jumlah responden sebanyak 14 orang (9 responden sebagai kelompok intervensi yang diberikan ROM dan hemodialisa, 5 responden sebagai kelompok kontrol yang menjalani hemodialisa saja).

\section{HASIL}

Tabel 1: menunjukkan karakteristik demografi dan klinik antara kelompok intervensi (ROM dan hemodialisa) dengan kelompok kontrol yang menjalani hemodialisa saja. Didapatkan data rata - rata umur responden pada kelompok intervensi (ROM + hemodialisa) 49,56 dan kelompok kontrol 42,20. Adapun jenis kelamin responden terbanyak pada perempuan yakni $6(42 \%)$ pada kelompok intervensi dan 2 $(14,3 \%)$ pada kelompok kontrol, sementara laki - laki 3 (21,4 \%) pada kedua kelompok. Untuk berat bedan kering responden terlihat jelas kelompok control lebih tinggi $(55,20)$ dibanding kelompok intervensi (ROM + hemodialisa) sebanyak $(47,57)$. Pasien gagal ginjal kronik yang menjalani hemodialisa kebanyakan disebabkan oleh hipertensi, pielonefritis dan diabetes mellitus. Saat menjalani hemodialisa, rata - rata durasi hemodialisa responden 4,02 $(0,16)$ pada kelompok intervensi (ROM + hemodialisa ) dan $3,88(0,22)$ pada kelompok control (Hemodialisa). Sementara frekuensi responden dalam menjalani hemodialisa setiap minggu didapatkan data bahwa baik 
kelompok intervensi maupun kelompok control 2 kali seminggu dan jumlah cairan yang dikeluarkan tiap sesi hemodialisa kebanyakan 2 liter yaitu 2,22 $(0,83)$ pada kelompok intervensi (ROM + hemodialisa) dan 2,20 $(0,84)$ pada kelompok control (hemodialisa) dengan kecepatan aliran darah yang dapat diobservasi pada mesin dializat yaitu $200 \mathrm{ml} / \mathrm{menit}$ pada kedua kelompok. Dari hasil pemeriksaan elektrolit didapatkan : nilai $\mathrm{Na}^{+}$pada kedua kelompok berada pada range yang normal (136 - 145) dengan uraian pada kelopok control 144,20 dan kelompok intervensi 139,22, begitupun dengan nilai $\mathrm{Cl}^{-}$ dan $\mathrm{K}^{+}$responden rata - rata hasilnya berada pada range normal (98-106). Pasien gagal ginjal kronik yang menjalani hemodialisa kebanyakan disebabkan oleh hipertensi, pielonefritis dan diabetes mellitus. Saat menjalani hemodialisa, rata - rata durasi hemodialisa responden 4,02 $(0,16)$ pada kelompok intervensi (ROM + hemodialisa ) dan 3,88 $(0,22)$ pada kelompok control (Hemodialisa). Sementara frekuensi responden dalam menjalani hemodialisa setiap minggu didapatkan data bahwa baik kelompok intervensi maupun kelompok control 2 kali seminggu dan jumlah cairan yang dikeluarkan tiap sesi hemodialisa kebanyakan 2 liter yaitu 2,22 $(0,83)$ pada kelompok intervensi (ROM + hemodialisa) dan 2,20 $(0,84)$ pada kelompok control (hemodialisa) dengan kecepatan aliran darah yang dapat diobservasi pada mesin dializat yaitu $200 \mathrm{ml} / \mathrm{menit}$ pada kedua kelompok. Dari hasil pemeriksaan elektrolit didapatkan : nilai $\mathrm{Na}^{+}$pada kedua kelompok berada pada range yang normal (136 - 145) dengan uraian pada kelopok control 144,20 dan kelompok intervensi 139,22, begitupun dengan nilai $\mathrm{Cl}^{-}$ dan $\mathrm{K}^{+}$responden rata - rata hasilnya berada pada range normal (98-106).

Tabel 2 yang uji paired t test untuk melihat perbedaan adekuasi hemodialisa $(U R R K t / V)$ sebelum dan setelah diberikan range of motion pada kelompok intervensi (ROM+HD) dan kelompok control (HD). Nilai URR pada kelompok intervensi $\mathrm{p}=$ 0,005 artinya terdapat perbedaan URR saat kunjungan 1 dengan kunjungan 8 , sementara pada kelompok control yang hemodialisa saja URR kunjungan 1 dengan kunjungan 8 $\mathrm{p}=0,39$ sehingga pada kelompok control tidak ditemukan perbedaan URR pada kunjungan 1 dan 8. Sehingga disimpulkan URR pada kelompok intervensi, terdapat perbedaan setelah kunjungan 8 . Pada nilai $\mathrm{Kt} / \mathrm{V}$ kunjungan 1 dan kunjungan 8 didapatkan nilai $p=0,11$ pada kelompok intervensi. Hal ini disimpulkan bahwa tidak terdapat perbedaan daan nilai $\mathrm{KtV}$ pada kelompok intervensi 
Dari tabel 3 di atas menyajikan hasil uji korelasi dukungan keluarga terhadap URR dan $\mathrm{Kt} / \mathrm{V}$ pada kelompok intervensi (ROM+hemodialisa) dan kelompok kontrol diperoleh nilai $\mathrm{p}>0,05$. Artinya tidak ada signifikan antara dukungan keluarga dengan nilai URR dan Kt/V. Pada kelompok intervensi untuk arah korelasinya positif dengan kekuatan korelasinya lemah, Kt/V arah korelasinya positif dengan kekuatan korelasinya kuat. Untuk kelompok kontrol nilai URR dimana kekuatannya sedang dengan arah korelasi positif $\mathrm{Kt} / \mathrm{V}$ arah korelasinya positif dengan kekuatan korelasi sedang.

Dari tabel 4 di atas dapat diketahui bahwa beberapa data karakteristik responden memiliki hubungan dengan perubahan nilai adekuasi (URR dan Kt/V) dengan nilai $\mathrm{p}$ $<0,05$. Yakni frekuensi terhadap Kt/V nilai $\mathrm{p}$ 0,04, kekuatan korelasi lemah ( $\mathrm{r}=-0,22)$, durasi $\mathrm{p}=0,00 \mathrm{r}$ 0,83, dan berat badan kering $\mathrm{p}=0,00 \mathrm{r}=0,41$. Untuk nilai URR berat badan kering $<0,05$. Dapat dilihat pada grafik 1

Grafik 1. Hubungan dengan frekuensi hemodialisa dengan mean $\mathrm{Kt} / \mathrm{V}$ di disimpulkan bahwa semakin sering seseorang melakukan hemodialisa dengan pemberian ROM maka nilai Kt/V mengalami penurunan. Dan dari grafik ini terdapat $21 \%$ hubungan frekuensi terhadap $\mathrm{Kt} / \mathrm{V}$ yang mampu dijelaskan dan $79 \%$ faktor lain yang memberi kontribusi.Untuk durasi hemodialisa terdapat hubungan dengan $\mathrm{Kt} / \mathrm{V}$, hal ini dapat dilihat pada grafik 2 .

Garafik 2. Hubungan durasi hemodialisa dengan $\mathrm{Kt} / \mathrm{V}$ disimpulkan bahwa semakin sering lama seseorang melakukan hemodialisa dengan pemberian ROM maka nilai Kt/V semakin meningkat. Dan dari grafik ini, 69\% hubungan durasi hemodialisa terhadap $\mathrm{Kt} / \mathrm{V}$ yang mampu dijelaskan dan $31 \%$ faktor lain yang memberi kontribusi. Untuk melihat hubungan $\mathrm{BB}$ kering dengan nilai $\mathrm{Kt} / \mathrm{V}$ dan URR. Hal ini dapat dilihat pada grafik 3

Grafik 3 Hubungan berat badan kering dengan nilai Kt/V disimpulkan bahwa semakin tinggi berat badan kering responden maka nilai Kt/V semakin menurun. Dan dari grafik ini $67 \%$ hubungan berat badan kering terhadap $\mathrm{Kt} / \mathrm{V}$ yang mampu dijelaskan dan $33 \%$ faktor lain yang memberi kontribusi. Selain hal yang di atas berat badan kering meliki hubungan dengan perubahan nilai URR. Perubahan nilainya dapat dilihat pada grafik 4.

Grafik 4 Hubungan berat badan kering dengan nilai URR disimpulkan bahwa 
semakin tinggi berat badan kering responden maka nilai Kt/V semakin menurun. Dan dari grafik ini 29\% hubungan berat badan kering terhadap URR yang mampu dijelaskan dan $71 \%$ faktor lain yang memberi kontribusi.

\section{PEMBAHASAN}

Dalam penilitian ini untuk mengukur adekuasi responden / pasien indikatornya adalah nilai ureum reduction ratio $(U R R)$ dan $K t / V$. Berdasarkan hasil penelitian untuk menghitung nilai $U R R$ maka, harus diukur ureum pre dan post. Selama hemodialisa terjadi proses ultrfiltasi dan difusi. Pada penelitian ini ditunjukkan nilai ureum prepost mengalami penurunan yang siknifikan setelah dilakukan range of motion pada kelompok intervensi. Hal ini sangat menentukan perubahan dari nilai $U R R$ yang menjadi salah satu indicator dalam menilai adekuasi hemodialisa. Ditinjau dari indikator adekuasi $U R R$ responden pada penelitian ini bahwa responden yang dilakukan rangen of mation dan hemodialisa mencapai nilai adekuasi (minimal > $65 \%$ ) dibandingkan dengan kelompok kontrol yang hanya menjalani hemodialisa saja. Hal ini terjadi karena rata - rata kelompok yang diberikan intervensi menjalani hemodialisa tiap kunjungan selama 4 jam bahkan terdapat responden yang mencapai 5 jam, sehingga dosis hemodialisa memenuhi $8-10$ jam. Perhimpunan Nefrologi Indonesia (Pernefri, 2003) menyatakan dosis HD yang ideal adalah $10-15 \mathrm{jam} / \mathrm{minggu}$ yang diberikan $2-3 \mathrm{kali}$ perminggu dengan lama HD antara $4-5$ jam perkali HD.

Secara teori dikatakan pada system metabolic otot saat latihan yaitu 1) system fosfokreatin - keratin, 2) system glikogenasam laktat 3) system aerobic. Sistem fosfokeratin ke ATP adalah penghantaran terjadi dalam waktu yang sangat singkat. Oleh karena itu, semua energy yang disimpan di dalam fosfokreatin otot dengan segera tersedia untuk kontraksi otot, seperti yang tersimpan dalam ATP. Jumlah gabungan dari sel ATP dan sel fosfokreatin disebut energy fosfagen. Keduanya bersama-sama dapat menyediakan daya ototmaksimal selama 8 sampai 10 detik. Sistem glikogen - asam laktat yakni glikogen yang disimpan di dalam otot dapat dipecah menjadi menjadi glukosa dan glukosa tersebut kemudian digunakan untuk energy yang disebut glikolisis, terjadi tanpa penggunaan oksigen oleh karena sebagai metabolic anaerobic. Selama glikolisis, setiap molekul glukosa dipecah menjadi dua molekul asam piruvat, dan energy dilepaskan untuk membentuk empat molekul ATP untuk setiap molekul glukosa awal. Kemudian asam piruvat kasuk ke mitokandria sel otot dan 
bereaksi dengan oksigen untuk membentuk lebih banyak molekul ATP. Akan tetapi bila tidak terdapat oksigen yang cukup untuk melangsungkan metabolism glukosa tahap kedua (tahap oksidatif), sebagian besar asam piruvat diubah menjadi asam laktat yang berdifusi ke luar dari sel otot masuk kedalam cairan interstisial dan darah. Oleh karena itu banyak glikogen otot berubah menjadi asam laktat tetapi dalam perjalanannya, sejumlah ATP yang sangat banyak dibentuk seluruhnya tanpa memakai oksigen (Guyton, 2008).

Hal ini sejalan dengan penelitian Berman, Erb, Kozier \& Snyder (2010) dikatakan bahwa latihan ROM memiliki keuntungan untuk memperbaiki kesehatan otot dan meningkatkan bersihan ureum dari sel/jaringan kulit. Latihan yang dilakukan merangsang pertumbuhan pembuluh darah yang kecil (kapiler) dalam otot. Hal ini membantu tubuh untuk lebih efisien menghantarkan oksigen ke otot, dapat memperbaiki sirkulasi secara menyeluruh dan menurunkan tekanan darah serta mengeluarkan hasil sampah metabolik yang mengiritasi seperti asam laktat dari dalam otot. Latihan yang adekuat meningkatkan efisiensi aliran darah, sehingga tubuh mengekskresikan sisa metabolisme secara lebih efektif. Latihan aeorobic secara rutin dapat membantu meningkatkan oksigenasi seluler menjadi lebih adekuat dan meningkatkan jumlah energi seluler (ATP). Selain URR, yang menjadi indikator dalam menilai adekuasi adalah nilai Kt/V. Berbeda yang dikatakan oleh Vaithilingam,I., (2010) bahwa tidak ada pebedaan penghapusan ureum pada kelompok intervensi maupun kelompok kontrol. Pada penelitian ini secara statistik tidak ditemukan adanya pengaruh range of motion pada nilai $\mathrm{Kt} / \mathrm{V}$, hal ini disebabkan karena rata - rata jumlah cairan yang dikeluarkan 2,2 liter, sehingga volume cairan yang ada dalam tubuh pasien masih besar, sementara frekuensi hemodialisa lebih dominan 2 kali seminggu dengan durasi tiap kali hemodialisa 3,8-4 jam.. Pada penelitian tersebut QB yang diberikan rerata 200 $\mathrm{ml} / \mathrm{menit}$. Sementara untuk memperoleh bersihan ureum yang optimal pada pasien dewasa, Qb diatur pada kecepatan antara 200 - 600 mL/menit. Pada Qb 200 mL/menit diperoleh bersihan ureum $150 \mathrm{~mL} /$ menit, sedangkan Qb 400 mL/menit diperoleh bersihan ureum $200 \mathrm{~mL} / \mathrm{menit}$ (meningkat 33\%) (Daugirdas, Blake, \& Ing, 2007).

Dalam mencapai adekuasi diperlukan dukungan dan peran serta dari keluarga selama menjalani terapi hemodialisa, baik saat menjalani hemodialisa maupun saat perawatan di rumah. Dukungan yang dimaksudkan adalah dukungan keluarga 
selama menjalani perawatan hemodialisa dan respon keluarga terhadap perawatan selama di rumah. Dari segi dukungan keluarga secara statistic tidak ditemukan adanya hubungan yang bermakna. Hal ini ditinjau dari respon keluarga yang semuanya mendukung serta mekanisme koping responden bahwa mereka semua telah menerima kondisinya dengan masa perawatan lebih dari 6 bulan dan keluarga semuanya mensupport dalam menjalani terapi hemodialisa.

Dari penelitian ini terjawab bahwa meskipun dukungan keluarga secara statistic tdak berpengaruh namun didapatkan bahwa hal yang memberi kontribusi itu adalah frekuensi HD, Durasi HD dan Berat badan Kering. Dari penelitan tersegut digambarkan bahwa semakin lama dan semakin semakin sering orang dalam menjalani terapi hemodialisa maka akan berpengaruh terhadap adequasi. Kondisi ini menunjukkan bahwa proses ultrafiltrasi dan difusi belum berjalan dengan optimal dan rentang waktu yang agak lama untuk menjalani hemodialisa selanjutnya sehinggan terbentuk dan tidak didukung dengan pembatasan diet dan kesadaran responden terhadap pembatasan cairan sehingga terjadi penumpukan sisa metabilisme yang semakin banyak. Hal tersebut berakibat pada perhitungan nilai adekuasi pascahemodialisa. Oleh karena V (volume distribusi cairan) dan berat badan kering yang menjadi pembilang mempunyai nilai yang cukup besar sehingga perhitungan akhirnya diperoleh nilai adekuasi yang kecil (Chayati, 2014). Dari hasil penelitian yang dilakukan oleh Malekmakan (2010), dikatakan bahwa Kt/V signifikannya lebih tinggi pada mereka yg mendapatkan 3 kali seminggu dibandingkan 2 kali perminggu. Perhimpunan Nefrologi Indonesia (Pernefri, 2003) menyatakan dosis HD yang ideal adalah $10-15$ jam/minggu yang diberikan 2 - 3 kali perminggu dengan lama HD antara 4 - 5 jam perkali HD. Target Kt/V yang ideal adalah 1,2 (URR 65\%) untuk pasien yang menjalani HD 3X/minggu dengan lama HD antara $4-5$ jam perkali HD.

\section{KESIMPULAN}

Penelitian ini menyimpulkan secara statistic tidak terdapat pengaruh pemberian range of motion terhadap perubahan $\mathrm{Kt} / \mathrm{V}$, namun terdapat secara klinis mengalami perubahan yang bermakna yakni nilai $\mathrm{Kt} / \mathrm{V}>$ 1,2 artinya mencapai standar adekuasi pada kelompok intervensi dan kelompok kontrol, namun nilai adekuasinya lebih tinggi pada kelompok intervensi dibanding kelompok kontrol. Pada dukungan keluarga secara statistic tidak ditemukan adanya hubungan yang bermakna terhadap perubahan nilai adequasi dan faktor yang memberi kontribusi 
adalah durasi hemodialisa, frekuensi hemodialisa dan berat badan kering.

\section{SARAN}

Diharapkan kepada peneliti selanjutnya untuk melakukan penelitian dengan jumlah sampel yang lebih banyak dan waktu yang lebih lama dalam menilai adekuasi hemodialisa dan menilai serum elektrolit pre dan post intervensi range of motion. Selain itu saat penelitian jenis mesin yang digunakan 2 jenis sehingga diupayakan menggunakan 1 jenis mesin dializat. Dan perlunya seorang perawat yang bertugas di ruang hemodialisa mengukur $U R R$ dan $K t / V$ pasien setiap bulannya dengan mengedukasi pasien terhadap lamanya proses hemodialisa dan mengobservasi $Q B$ dan mengkaji keluhan pre, intra serta post dialisis.

\section{UCAPAN TERIMA KASIH}

Terima kasih kami ucapkan kepada Direktur Akper Muhammadiyah, staf dan Direktur Rumah Sakit Umum Daerah Labuang Baji Makassar serta Kepala Ruangan hemodialisa dan staff laboratorium Cahya atas bantuan selama penelitian.

\section{DAFTAR PUSTAKA}

Alimanesh, M., Haghpanah,A., Haghpanah,S., Khajehdehil, P., Malekmakan, A., Malekmakan, L., ... Pakfetrat, M. 2010. Dialysis adequacy and kidney disease outcomes quality initiative goals achievement in an Irian hemodialysispopulation.IJKD : 2010;4:39-43. Diakses dari website http://www.ncbi.nlm.nih.gov/pubmed/20081303

Armiyati, Chanif, Yuwono. 2013. Pengaturan kecepatan aliran darah (quick of blood) terhadap rasio reduksi ureum pada pasien penyakit ginjal kronik yang menjalani hemodialisis di unit hemodialisis RSUD kota Semarang. Prosiding Konferensi Nasional PPNI Jawa Tengah 2013.

Bayhakki .2013. Seri asuhan keperawatan klien gagal ginjal kronik. Jakarta : EGC.

Black, J. M., \& Hawks, J. H. 2014. Keperawatan Medikal Bedah Manajemen Klinis Untuk Hasil Yang Diharapkan Edisi 8 Buku 2. Singapura: Elsevier.

Berman, A., Erb, G., Kozier, B., \& Snyder, S. J. 2010. Buku ajar fundamental keperawatan konsep proses dan praktik. Jakarta : EGC.

Bevington, A., Bishop, N.C., Clapp, E.L., Feehally, J., Kosmadakis, G.C., Smith, A. C.,...Viana, J.L. 2010. Physical exercise in patients with severe kidney disease. Nephron clinical practice 2010; 115:c7-c16.doi:10.1159/000286344

Burns, N., \& Groove, S.K. 2011. Understanding Nursing Research (5th ed). USA: Elsevier.

Chayati,N., Ibrahim, K., \& Komariah, M. 2014. Predictor of dialysis adequacy in hemodialysis 
patients in PKU Muhammadiyah Hospital Yogyakarta. Diakeses di website http://journal.fk.unpad.ac.id/index.php/mkb/article/view/410

Chen, L., Cheng, J., Sheng, K., Wu, C \& Zhang, P. 2014. Intradialytic exercise in hemodialysis patients: A systematic review and meta-analysis. Am J Nephrol, 40: 478-490. Doi: $10.1159 / 000368722$.

Daugirdas, J. T. \& Ing. 2007. Physiologic Principles and Urea Kinetic Modeling. Philadelpia: Lippincott Williams \& Wilkins.

Hajbaghery, MA., Ilali, E., Makhlough, A., Mohseni, R., \& Zeydi, AE. 2013. The effect of intradialytic aerobic exercise on dialysis efficacy in hemodialysis patients: a randomized kontrolled trial. Oman Medical Journal, 28(5), 345-349. Doi: 10.5001/omj.2013.99

Ilali, E.,Makhlough A., Mohseni,R., \& Shahmohammadi. 2012. Effect Of Intradialytic Aerobic Exercise On Serum Electrolytes Levels In Hemodialysis Patients. Iranian Journal of Kidney desease IJKD 2012 ;6:119-123. http; //www.ijkd.org/ /index.php/ijkd/article/viewFile/597/387

Jung, T \& Park,S. 2011. Intradialytic exercise program for hemodialysis patient. Chonnam Med J 2011; 47:61-65. http://dx.doi.org/10.4068/cmj.2011.47.2.61

Kirkman, Roberts, Kelm, Wagner, Jibani \& Macdonald. 2013. Interaction between Intradialytic Exercise and Hemodialysis Adequacy. Am J Nephrol; 38: 475-482. DOI:10.1159/000356340.

KDOQI. 2012. Clinical practice guidelines for hemodialysis adequacy. 10 April 2015. http://www.kidney.org/professionals/kdoqi/

KDOQI. 2015. Clinical practice guidelines for hemodialysis adequacy: 2015 update. Diakses dari halaman website https://www.kidney.org/professionals/guidelines/hemodialysis

King-Vanvlack C.E., Parsons, T.K., \& Tosselmire E.D., (2006). Exercise Training During Hemodialysis Improves Dyalisis Efficacy And Physical Performance. Exercise Arch phys med rehabil: 2006; 87:680-7. Diperoleh dari http://www.interscience.com

National Kidney and Urologic Disease Information Clearinghouse. 2009. Kidney and urologic disease statistic for the United States (NIH Publication No.09-3895). Retrieved from http: //www.niddk.nih.gov/kudiseases/kidney/pubs/kustats 
Nekada,CD., 2012. Hubungan antar dukungan keluarga kepatuhan pasien gagal ginjal dalam menjalani hemodialysis di RSUP DR. Soeradjietirtonegoro Klaten

Painter, P. 2013. Exercise in patients with end-stage renal disease. Diakses dari website http://web.missouri.edu/ brownmb/pt415/case/burnett/ACSM-Resource.C.34-ESRD.pdf

Price, S. A., \& Wilson, L. M. 2005. Patofisiologi konsep klinis proses - proses penyakit volume 2 edisi 6. Jakarta: EGC.

Riset Kesehatan Dasar .2013. Prevalensi penyakit gagal ginjal kronik 2013.

Sunarni. 2009. Hubungan antar dukungan keluarga dengan kepatuhan menjalani hemodialisa pada penderita gagal ginjal.

Tonapa. 2016 Hubungan Dukungan Keluarga Dengan keputusan Insiasi Hemodialisa Pada Pasien Penyakit Ginjal Kronik Di ruang e-journal keperawatan vol 4 Nomor 1, Februari 2016

The United States Renal Data System (USRDS).2012. Prevalence of reported CKD on 2012. Diperoleh dari http://usrds.org 
Tabel 1 Karakteristik demografi dan klinik

\begin{tabular}{|c|c|c|c|}
\hline \multirow{3}{*}{ Karakteristik } & \multicolumn{2}{|c|}{ Kelompok } & \multirow{3}{*}{$P$} \\
\hline & $\begin{array}{l}\text { ROM dan } \\
\text { hemodialisa }\end{array}$ & Hemodialisa & \\
\hline & $(\mathrm{n}=9)$ & $(n=5)$ & \\
\hline Umur, Mean (SD) & $49,56(12,82)$ & $42,20(3,27)$ & $0,12 \dagger$ \\
\hline BB Kering, Mean (SD) & $47,56(6,91)$ & $55,20(10,57)$ & $0,06 \dagger$ \\
\hline $\begin{array}{l}\text { Frekuensi Hemodialisa, } \\
\text { Mean (SD) }\end{array}$ & $2,22(0,44)$ & $2,60(0,54)$ & $0,09 \dagger$ \\
\hline $\begin{array}{l}\text { Durasi Hemodialisa, } \\
\text { Mean (SD) }\end{array}$ & $4,02(0,16)$ & $3,88(0,22)$ & $0,10 \dagger$ \\
\hline Uf Goal, Mean (SD) & $2,22(0,83)$ & $2,20(0,84)$ & $0,48 \dagger$ \\
\hline $\begin{array}{l}\text { Quick Blood, Mean } \\
\text { (SD) }\end{array}$ & $199,11(11,78)$ & $200,20(13,59)$ & $0,44 \dagger$ \\
\hline $\mathrm{Na}^{+}$, Mean (SD) & $139,22(2,43)$ & $144,20(10,50)$ & $0,09 \dagger$ \\
\hline $\mathrm{K}^{+}$, Mean $(\mathrm{SD})$ & $4,64(0,54)$ & $4,36(0,70)$ & $0,10 \dagger$ \\
\hline $\mathrm{Cl}^{-}$, Mean (SD) & $105,67(2,29)$ & $106,20(2,77)$ & $0,35 \dagger$ \\
\hline \multicolumn{4}{|l|}{ Jenis kelamin, $\mathrm{n}(\%)$} \\
\hline Laki - laki, & $3(21,4)$ & $3(21,4)$ & $0,17 \dagger$ \\
\hline Perempuan & $6(42,9)$ & $2(14,3)$ & \\
\hline \multicolumn{4}{|l|}{ Etiologi, n (\%) } \\
\hline Hipertensi & $5(35,7)$ & $1(7,1)$ & $0,19 \dagger \dagger$ \\
\hline Pielonefritis & $2(14,3)$ & $2(14,3)$ & \\
\hline $\mathrm{DM}$ & $1(7,1)$ & $2(14,3)$ & \\
\hline Glomerulosnefritis & $1(7,1)$ & $0(0,0)$ & \\
\hline
\end{tabular}

$\overline{\text { Keterangan : menggunakan } \dagger \text { Uji independent } \mathrm{t} \text { test, } \alpha=0,05 \text { dan } \dagger \dagger \mathrm{Uji} \text { chi }- \text { square }}, \alpha$ $=0,05$ 
Tabel 2 Perbedaan adekuasi hemodialisa (URR dan $K t / V$ ) sebelum dan setelah diberikan range of motion pada kelompok intervensi (ROM+HD) dan kelompok control (HD)

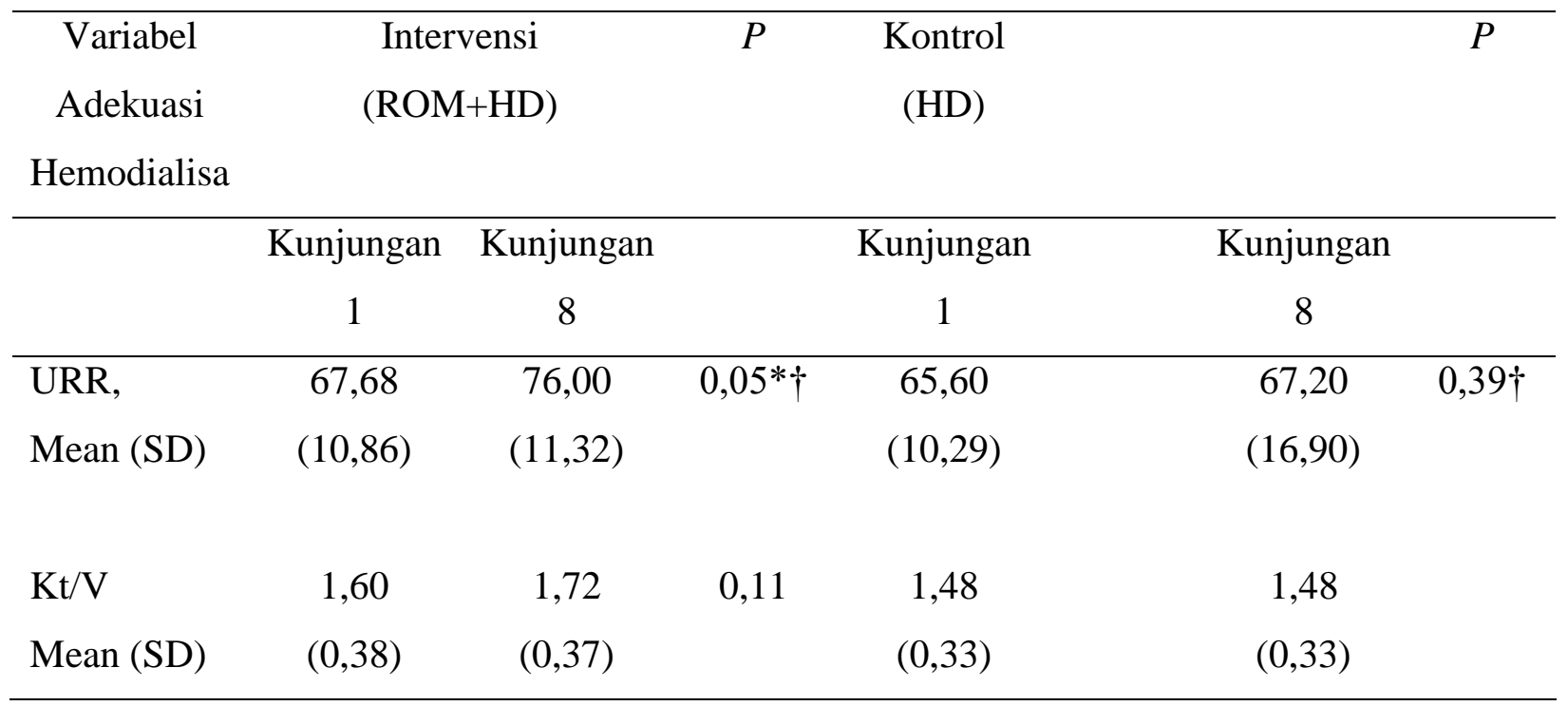

Keterangan : Menggunakan $\dagger$ Uji paired t test, $\alpha=0,05$

Tabel 3 Hubungan dukungan keluarga selama menjalani terapi hemodialisa pada kelompok intervensi (ROM dan hemodialisa) dengan kelompok kontrol

\begin{tabular}{|c|c|c|c|c|c|c|c|c|}
\hline \multirow{3}{*}{ Variabel } & \multicolumn{4}{|c|}{ Kelompok Intervensi } & \multicolumn{4}{|c|}{ Kelompok Kontrol } \\
\hline & \multicolumn{2}{|c|}{ URR } & \multicolumn{2}{|c|}{$\mathrm{Kt} / \mathrm{V}$} & \multicolumn{2}{|c|}{ URR } & \multicolumn{2}{|c|}{$\mathrm{Kt} / \mathrm{V}$} \\
\hline & $\mathrm{R}$ & $p$ & $\mathrm{r}$ & $p$ & $\mathrm{R}$ & $p$ & $\mathrm{R}$ & $p$ \\
\hline Dukungan & 0,33 & 0,19 & 0,60 & 0,43 & 0,55 & 0,17 & 0,44 & $0,23 \dagger$ \\
\hline Keluarga & & & & & & & & \\
\hline
\end{tabular}

Keterangan: Menggunakan $\uparrow$ Uji pearson correlation, $\alpha<0,05$

Tabel 4 Hubungan data karakteristik terhadap URR dan Kt/V

\begin{tabular}{cccccc}
\hline Variabel & \multicolumn{2}{c}{$\mathrm{Kt} / \mathrm{V}$} & \multicolumn{3}{c}{$U R R$} \\
& $\mathrm{r}$ & & $p$ & $\mathrm{r}$ & $p$ \\
\hline Umur & $-0,31$ & & 0,14 & $-0,18$ & $0,54 \dagger$ \\
& & & & \\
\hline
\end{tabular}




\begin{tabular}{ccccc}
\hline Frekuensi & $\begin{array}{c}-0,22 \\
0,04^{*}\end{array}$ & $-0,28$ & 0,17 \\
& 0,83 & 0,29 & 0,15 \\
& $0,00^{*}$ & & & \\
\hline Durasi & $-0,41$ & & $-0,27$ & $0,02^{*}$ \\
& $0,00^{*}$ & & & \\
\hline BB kering & $-0,34$ & 0,12 & 0,29 & 0,15 \\
& & & & \\
\hline QB & $-0,45$ & 0,05 & $-0,14$ & 0,31 \\
\hline UF Goal & & & & \\
\hline
\end{tabular}

Keterangan: Menggunakan $\uparrow$ Uji pearson correlation
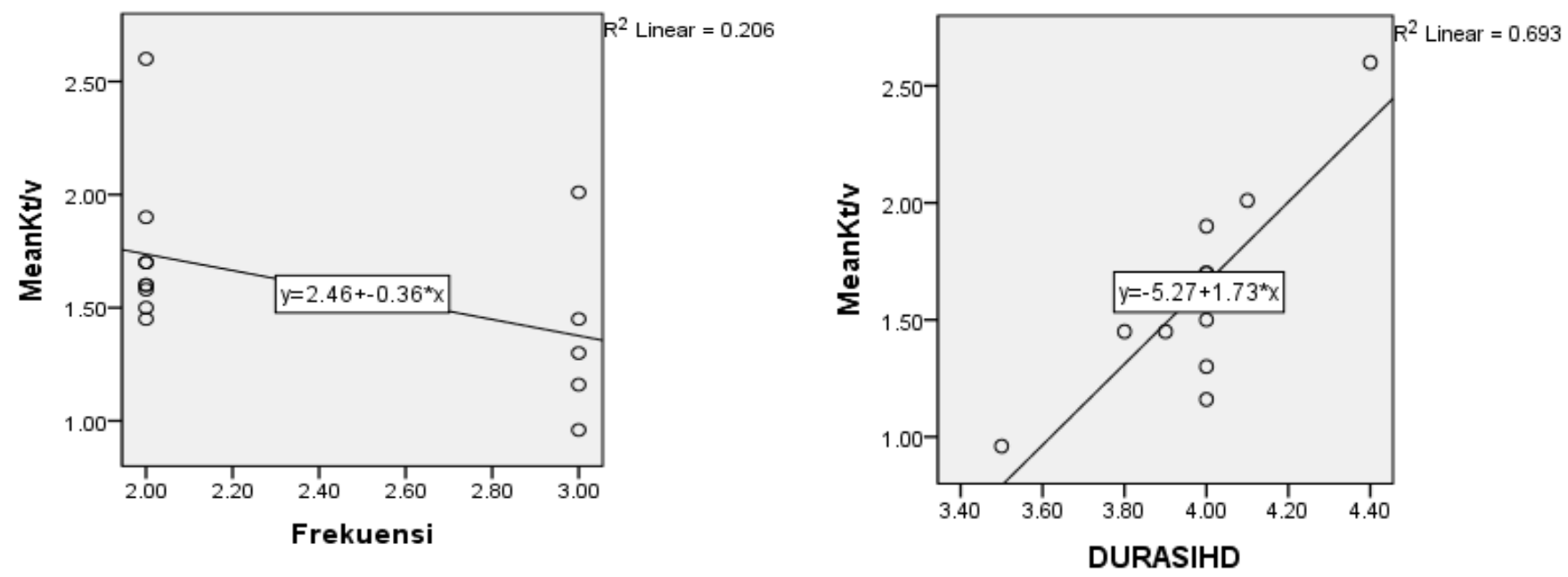

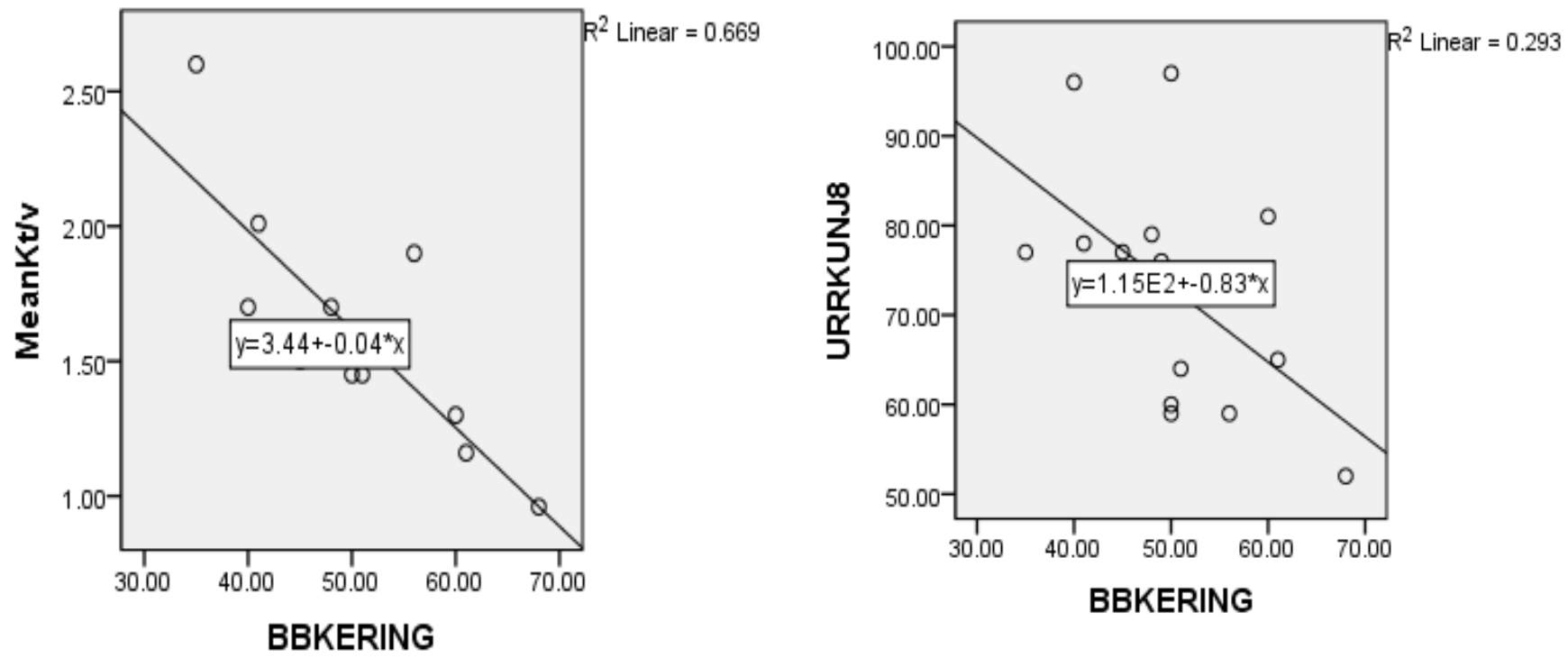